Ethiopian Journal of Environmental Studies \& Management 8(Suppl. 2): 893 - 905, 2015.

ISSN:1998-0507

doi: http://dx.doi.org/10.4314/ejesm.v8i2.4S

Submitted: May 19, 2015

Accepted: November 05, 2015

\title{
THE RELATIONSHIPS BETWEEN ORGANIC AND INORGANIC FERTILIZERS AND MAIZE GROWTH AND YIELD IN TWO LAGOS FARM COMMUNITIES
}

\author{
ADEDAYO, V., ADEYEMI, 0. AND FASHUA, K.
}

Department of Geography, University of Lagos, Nigeria

\begin{abstract}
The paper aims to examine the effect of organic and inorganic fertilizers on maize yield and growth within and between two farm communities in Lagos. It analyses the correlates of the crop growth and yield of maize served with organic and inorganic fertilizers between and within locations and also determine the differences in the yield of maize served with organic and inorganic fertilizers between the study locations based on soil type.Two main types of survey were adopted for this research in order to gather both qualitative and quantitative data. These are: field experiment social survey and desk research. An experiment was carried out to determine the effects of organic fertilizer (Poultry manure) and inorganic fertilizer (NPK 15,15,15) on the growth and yield of maize between December $27^{\text {th }} 2012$ and March 27th 2013 in two farming communities - Agbowa and Offin. The growth parameters adopted were plant height, number of leaves, stem girth and leave area which were measuredat four (4) and twelve (12) Weeks After Planting while cob length and weight of grains per plot were estimated to determine the yield. The result revealed no significant difference in maize growth within each of the study locations (4 and 12 weeks after planting) i.e. at the critical value of 3.682 P: $0.76>0.05 ; P: 0.88>0.05 ; P: 0.93>0.05$ andP: $0.66>0.05$ respectively, but there was a significant difference in maize growth between the two study locations (4 and 12 weeks after $p$ lanting) i.e. with a $t$ value of $3.794, P: 0.001<0.05$ and with a $t$ value of 2.972, $P: 0.031<0.05$ respectively. There was also a significant difference in maize yield within each of the study locations i.e. with a $t$ value of 4.179, P: $0.009<0.05$ and $t$ value of 3.601, P: $0.016<0.05$ respectively and between the two study locations at harvesting (12 weeks after planting) i.e. at the $t$ value of 2.972, P: $0.031<0.05$. The paper thus concludes that farmers should be educated and equipped with practical skills to improve the use and application of all types of fertilizer for increased yield, income and sustainable maize production.
\end{abstract}

Key Words: Correlate, Organic fertilizer, Inorganic fertilizer, Maize growth, Maize yield

\section{Introduction}

Maize (Zea mays L.) is a cereal monoecious shrub originated from South and Central America and introduced to West Africa by the Portuguese in the $10^{\text {th }}$ century (Iwena, 2012). It is one of the top three cereal crops grown by both peasant and commercial farmers worldwide (Onwueme and Sinha, 2009). Globally, it is ranked third in terms of both production and consumption, following rice and wheat (Yayock et al., 2006; Romains, 2011). About $66 \%$ of maize produced worldwide is used for feeding livestock, 25\% forhuman consumption and $9 \%$ for industrial and seed purposes (Romains, 2011).Currently, Maize has become an increasingly important biofuel, both in the 
form of corn oil (used as bio-diesel) and ethanol (an alcohol fermented and distilled from the processed kernels), which is blended with petroleum-based gasoline in various proportions for use as fuel (Romains, 2011; IITA, 2007).

According to Hileman (2008), the value of organic fertilizer stems from the fact that it has been used successfully on wide variety of crops either as a single plant nutrient source or in supplementation with inorganic fertilizers. Hileman (2008) also stressed much on organic fertilizer which according to him returns huge proportion of plant food such as $\mathrm{N}, \mathrm{P}, \mathrm{K}$. Boateng et al. (2002) and Frempong et al. (2006) reported an increase in the number of leaves of okro, root, stem, and leaf fresh weight of the okra plant in three folds than the plots with cow dung and compost and the control. This assertion is supported by Frempong et al. (2006), who recorded high yield of the number of pods of okro in two folds over the control. Boateng et al. (2007) also recorded a higher grain yield and biomass of maize when organic fertilizer (6-8 tones/ha) was applied than inorganic fertilizer. Ewulo et al. (2008), reported higher yields of tomato for organic fertilizer than inorganic (NPK) and observed 25 tons/ha yield of tomato as Masud et al. (2009), observed significant increase in plant height, fruit length, fruit weight, fruit diameter and fresh fruit yield in organic fertilizer treatment than the control. Baum et al. (2001) and Agyarko et al. (2006), in their studies observed that higher yield of maize was obtained with 10tons/ha of organic fertilizer than with adequate application of $\mathrm{N}$ and $\mathrm{P}$ inorganic fertilizers, and heavier mean root and shoot weight of carrot per plant were recorded.

Chandrashekara and Riazuddin (2000) evaluated the fertilizer requirement of maize from fertilizer adjustment equations for attaining specific yield targets in farmer's field. The results indicated that fertilizer requirement of $\mathrm{N}, \mathrm{P}_{2} \mathrm{O}_{5}$ and $\mathrm{K}_{2} \mathrm{O}$ were found to be $1.66,1.12$ and $1.55 \mathrm{~kg}$, respectively for producing one quintal of maize grain yield. Onasanya et al. (2009), conducted an experiment in southern Nigeria with twelve different rates of nitrogen and phosphorus fertilizers on growth and yield of maize (Zea mays L.). They revealed that an application of 120 $\mathrm{kg} \quad \mathrm{N}$ and $40 \mathrm{~kg} \mathrm{P}$ ha-1 significantly increased the growth and yield (7.13 t ha1) of maize than other treatments \{ Trinh et al. (2008), Suryavamshi et al. (2008), Mahala et al., 2006, Jayaprakash et al. (2006) and Dhillon et al. (2006) .

With the various studies showing the correlates between organic and inorganic fertilizers and maize growth and yield, a major concern has been the actual effect of fertilizer on maize in terms of growth and yield.

According to Iwena (2010), proper application of appropriate fertilizer to farmland ensures improved yield in agricultural production, but also a factor of soil properties, types and stage of crop development, time of application, available labour and equipment, existing soilfertility levels, fertilizer nutrient content, crop nutrient needs, site limitations, slope, runoff potential, and leaching potential. In addition, the Georgia Environmental Protection Division (GEPD, 2012) asserted that proper application of fertilizer on farmland requires a nutrient management plan - a collection of best management practices that assure the appropriate use of both organic and inorganic fertilizers to provide crop nutrient requirements while simultaneously protecting surface and ground waters from over-application.

The correlates and nexus among the many factors that influence crop input, and output and the knowledge gaps provide information on the distinctiveness of places as it affects crop yield and growth. Obafemi (2010) argued that variations over 
space occur as a result of interplay of several factors such as soil and socialeconomic forces. This paper aims to examine the effect of organic and inorganic fertilizers on maize yield and growth in two farm communities in using Agbowa and Offin in Lagos as a case study. The paper analyses the correlates of the crop growth and yield of maize served with organic and inorganic fertilizers between and within locations and also determine the differences in the yield of maize served with organic and inorganic fertilizers between the study locations.

\section{Study Area}

Agbowa-Ikosi is a town in Epe Local Government Area of Lagos State. It is located on latitude $6^{\circ} 38^{\prime} 36^{\prime \prime} \mathrm{N}$ and Longitude $3^{\circ} 42^{\prime} 44^{\prime \prime} \mathrm{E}$. and Ofin on the other hand is a coastal town in the Southern part of Ikorodu (a prominent
Local Government Areas in Lagos State). It lies on Latitude $6^{\circ} 32^{\prime} 23^{\prime \prime} \mathrm{N}$ and longitude $3^{\circ} 29^{\prime} 59^{\prime \prime} \mathrm{E}$ (DMS) with an altitude of $37 \mathrm{~m}$ above the sea level (Figure 1). The two study locations fall within the same climatic belt. The annual rainfall is above $2000 \mathrm{~mm}$ leading to high humidity and less severity of drought condition. Average temperature is above $28^{\circ} \mathrm{C}$ (Iwena, 2008). Agbowa-Ikosi has a population of over 10,000 people with the majority of the population being Ijebus while Ofin has a population of over 25,000 people with the majority of the population being Ijebus (Olulade, 2012).Both communities share similar economic activities including; crop cultivation, manufacturing, fishing, hunting, sand excavation and farming etc. Major food crops include; cassava, rice, plantain, yam, maize, etc.

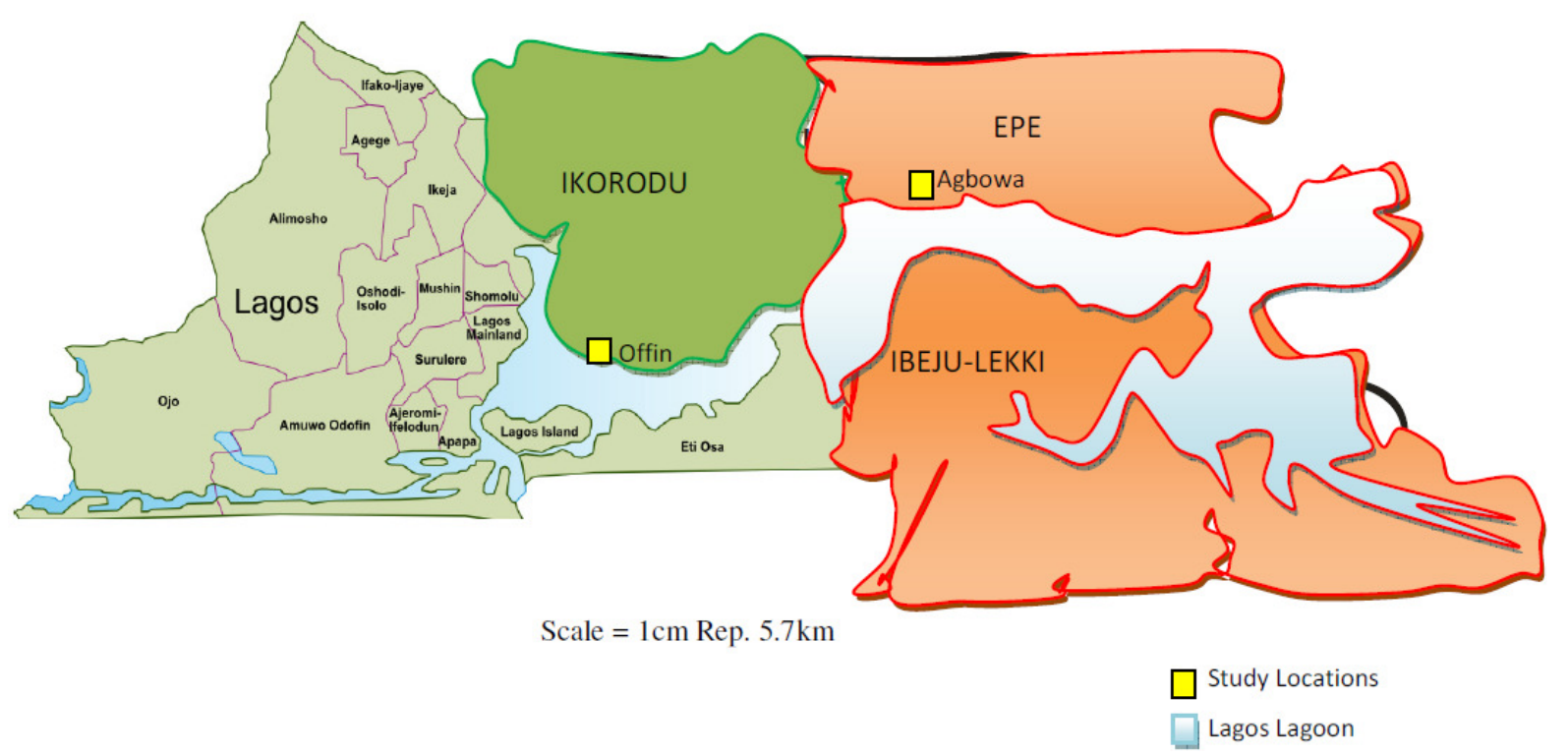

Figure 1: Map of LagosState showing study locations

Source: Retrieved fromhttp://google.com and modified (2013)

\section{Method}

\section{Data Sources}

Two main types of survey were adopted for this research in order to gather both qualitative and quantitative data. These are: field experiment, social survey and desk research. The experimental survey was carried out to measure and quantify fertilizer applied and growth and yield of maize. The procedures adopted are: 


\section{Experimental Design}

An experiment to determine the effects of organic fertilizer and inorganic fertilizer (NPK 15,15,15) on the growth and yield of maize which was conducted between December $27^{\text {th }} 2012$ and March 27th 2013 in two farming communities - Agbowa and Offin. The field experiment was laid out in a Randomized Complete Block
Design (RCBD) consisting of three treatments in each of the two locations. The treatment were $0 \mathrm{~kg}$ NPK $16 \mathrm{~m}^{2}+0 \mathrm{~kg}$ Poultry Manure $16 \mathrm{~m}^{2}\left(\mathrm{~T}_{1}\right)$ as control; $0.72 \mathrm{~kg}$ NPK $16 \mathrm{~m}^{2}+0 \mathrm{~kg}$ Poultry Manure $16 \mathrm{~m}^{2}\left(\mathrm{~T}_{2}\right)$ as inorganic and $4.8 \mathrm{~kg}$ Poultry Manure $16 \mathrm{~m}^{2}+0 \mathrm{~kg}$ NPK $16 \mathrm{~m}^{2}\left(\mathrm{~T}_{3}\right)$ as organic manure (Table 1).

Table 1: Treatments for the experiment

\begin{tabular}{|c|c|c|c|}
\hline Treatments & $\begin{array}{l}\text { Inorganic Fertilizer } \\
\text { (NPK 15-15-15) }\end{array}$ & $\begin{array}{l}\text { Poultry } \\
\text { (PM) }\end{array}$ & Rate per Hectare \\
\hline T1 (Control) & - & - & - \\
\hline T2 (Sole NPK) & $0.72 \mathrm{Kg} / 16 \mathrm{~m}^{2}$ & - & $450 \mathrm{~kg} / 10000 \mathrm{~m}^{2}(\mathrm{~h})$ \\
\hline T3 (Sole PM) & - & $4.8 \mathrm{~kg} / 16 \mathrm{~m}^{2}$ & $3 \mathrm{t}$ or $3000 \mathrm{~kg} / 10000 \mathrm{~m}^{2}(\mathrm{~h})$ \\
\hline
\end{tabular}

Maize Cultivation (Land Acquisition, Clearing and Preparation)

The piece of land use for the experiment in the two study locations were voluntarily released by the community leaders after consultation and statement of purpose. The lands were cleared and hoed to pulverize the soil in the two study locations. The fields were then marked out into 3 plots. The size of each plot was $4 \mathrm{~m}$ $\mathrm{x} 4 \mathrm{~m}$ with a distance of $0.5 \mathrm{~m}$ between the plots. The land area used in each of the study locations was $13.5 \mathrm{x} 4 \mathrm{~m}\left(54 \mathrm{~m}^{2}\right)$

\section{Planting and Cultural Practices}

Maize seeds (TZB-SR), a widely grown late maturing maize cultivar were sown on $27^{\text {th }}$ December. The seeds were treated with Apron plus to control soil pathogens before sowing. Three seeds were planted per hole at a spacing of 0.75 x $0.25 \mathrm{~m}(75 \mathrm{~cm} \times 25 \mathrm{~cm})$. Maize seedlings were later thinned to one plant per stand at 14 days after sowing. The treatments (NPK $15,15,15$ and Poultry fertilizers) were applied on separate portions (T2 \& T3 respectively). The NPK 15, 15, 15 fertilizer was applied two weeks after planting by spot placement using a ratio of $450 \mathrm{~kg}$ (9 bags) of NPK 15:15:15 fertilizer per hectare in two splits applied at planting $\left(150 \mathrm{~kg} / \mathrm{h}\right.$, i.e. $\left.0.24 \mathrm{~kg} / 16 \mathrm{~m}^{2}\right)$ and 6 weeks after planting $\left(300 \mathrm{~kg} / \mathrm{h}\right.$, i.e. $\left.0.48 \mathrm{~kg} / 16 \mathrm{~m}^{2}\right)$ while the poultry fertilizer was applied two months before planting to allow decomposition. Weeds were controlled manually by weeding to reduce competition for space, water, light and nutrients between crops and weeds. The field borders were kept clean to minimize encroachment by insects and rodents. Manual irrigation was adopted during the experiment (5 days in a week and two times in a day - early in the morning and late in the evening). The harvesting was done at maturity - 12 weeks after planting (March 27 ${ }^{\text {th }}, 2013$ ) to determine the yield.

\section{Effects of Organic and Inorganic} Fertilizer on Maize Growth

To determine the effect of organic and inorganic fertilizer on maize growth, an experimental design was undertaken and the following procedures adopted for each of the growth parameters:

\section{Plant Height}

The height six randomly selected plants marked A, B, C, D, E, and F within each plot was measured using a carpenter's tape. The height was measured from the ground level to the top-most leaf and 
recorded. This was done in the $4^{\text {th }}$ and $12^{\text {th }}$ week after planting.

\section{Number of Leaves}

Visual counting of leaves on the six randomly selected plants was made and the number was recorded for each plant.

\section{Stem Girth}

The cob girth of the six selected maize plants was measured with a tailor's tape for each plot and the values recorded.

\section{Leave Area}

The leaf area was determined by the non-destructive length $\mathrm{x}$ width method described by Subedi et al, (2010)using the relation: Leaf Area $=0.75$ (length $\mathrm{x}$ width), where 0.75 is a constant. The leaves (length and width) of six samples were measured with a tailor's tape for each plot and the leaf area determined.

\section{Effects of Organic and Inorganic} Fertilizer on Maize Yield

In order to analysis the effect of organic and inorganic fertilizer on maize yield, an experimental design was undertaken and the following procedures adopted the output/yield parameters:

\section{Cob Length}

The length of the six de-husked maize cobs per plot was measured with a tape. This was done in the $12^{\text {th }}$ week after planting being harvesting time.

\section{Weight of grains per plot (yield)}

The weights of the six cobs for each treatment plot were added to obtain the weight of grains per plot at $12^{\text {th }}$ week after planting.

\section{Social Survey}

Social survey was used to gather data to determine the effect of socio-economic characteristics of farmers on choice of fertilizer used. The data used was obtained through the use of structured questionnaire from a cross-section of smallholder food crop farmers. Data collected included demographic characteristics of the farmers; socio-economic and farm-specific variables. A random sampling technique was employed to select representative of food crop farmers for the study. The first stage involved the selection of two Local Government Areas (Epe and Ikorodu) each from the two agricultural zones in the state while the second stage involved random selection of two communities from the two Local Government Areas having varying soil properties. In the final stage, Fifty (50) farmers were randomly selected from the each community (Agbowa-Ikosi and Offin from Epe and Ikorodu Local Government Areas respectively) with the help of the State ADP Extension Agents. Therefore, a total of 100 farmers were sampled and used for the study.

\section{Desk Search}

Review of literature was carried out through textbooks, articles/journals and internet surfing.

\section{Hypothesis Testing and Analytical tool}

To effectively determine the effect of fertilizers on crops the following hypotheses were tested:

there is no significant difference in the growth of maize served with organic and inorganic fertilizers between and within locations in the study area

there is no significant difference in the yield of maize served with organic and inorganic fertilizers between and within locations in the study area

\section{Data Analysis}

Data collected were statistically analyzed and tested using Anova, while Standard Error of Differences (SED) was used to separate the means while the paired samples statistics were used to establish statistical differences in between measured parameters.

\section{Results and Discussions}

Effect of Organic and Inorganic Fertilizers on Maize Growth four Weeks after Planting (4 WAP)

The result of the effect of organic and inorganic fertilizer on growth of maize as 
indicated on Figure 2 revealed that, the highest growth performance regarding maize height, number of leaf, leaf length, leaf width, leaf area and stalk girth 4Weeks After Planting (4WAP) was found in maize served with inorganic fertilizer within each of the study locations (Agbowa and Offin) while slight differences were noticed in the growth parameters between the organic fertilizer and control treatments during the same planting period.

Table 2: Field Measurement of Maize Growth Parameter - 4 and 12 weeks after planting

\begin{tabular}{|c|c|c|c|c|c|c|c|c|c|c|c|c|}
\hline \multirow[b]{2}{*}{$\begin{array}{l}\text { GROWTH } \\
\text { INDICES }\end{array}$} & \multicolumn{3}{|c|}{$\begin{array}{c}\text { Agbowa } \\
\text { 4weeks after } \\
\text { planting }\end{array}$} & \multicolumn{3}{|c|}{$\begin{array}{c}\text { Offin } \\
\text { 4weeks after } \\
\text { planting }\end{array}$} & \multicolumn{3}{|c|}{$\begin{array}{c}\text { Agbowa } \\
\text { 12weeks after planting }\end{array}$} & \multicolumn{3}{|c|}{$\begin{array}{c}\text { Offin } \\
\text { 12weeks after } \\
\text { planting }\end{array}$} \\
\hline & 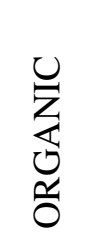 & 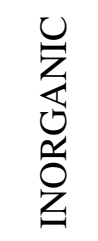 & 高 & 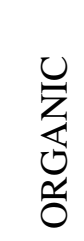 & 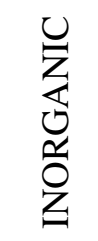 & לֶ. & 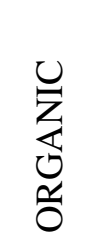 & 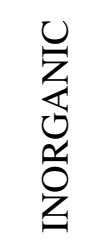 & 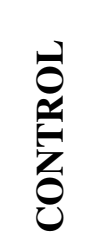 & 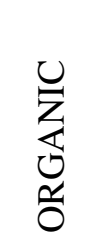 & 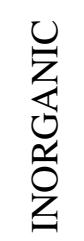 & ס \\
\hline Height (m) & 0.86 & 1.18 & 0.78 & 0.72 & 0.89 & 0.87 & 2.46 & 2.19 & 2.32 & 2.62 & 2.04 & 1.97 \\
\hline No of Leaf & 10.0 & 13.00 & 11.50 & 8.83 & 10.67 & 9.50 & 12.17 & 11.33 & 10.50 & 11.17 & 9.33 & 8.50 \\
\hline leaf Length (m) & 5.20 & 8.91 & 5.40 & 4.12 & 5.35 & 3.38 & 10.59 & 8.57 & 8.41 & 7.80 & 4.81 & 3.66 \\
\hline Leaf Width (m) & 0.50 & 0.80 & 0.47 & 0.30 & 0.41 & 0.22 & 1.04 & 0.94 & 0.82 & 0.73 & 0.45 & 0.31 \\
\hline Leaf Area (m) & 1.96 & 5.37 & 1.94 & 0.97 & 1.65 & 0.62 & 8.82 & 6.12 & 5.18 & 4.28 & 1.59 & 0.85 \\
\hline Girth (m) & 0.07 & 0.09 & 0.05 & 0.03 & 0.04 & 0.10 & 0.09 & 0.08 & 0.07 & 0.06 & 0.04 & 0.04 \\
\hline
\end{tabular}

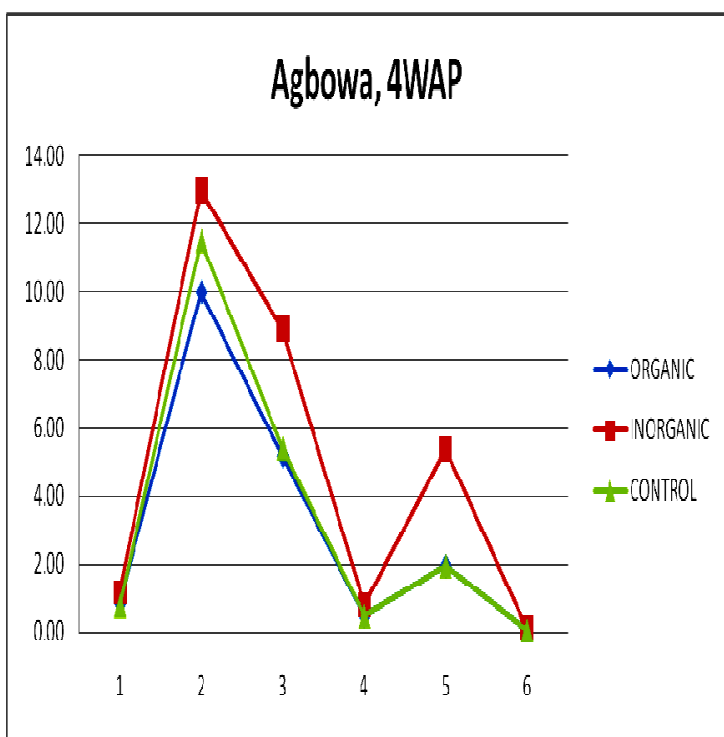

(a)

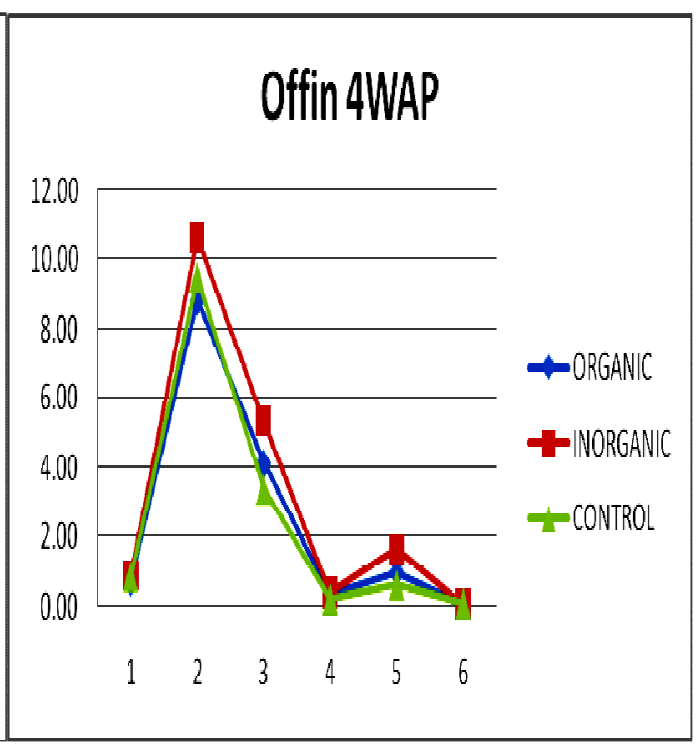

(b)

Figure $2 \mathrm{a}$ and b: Estimated difference in maize growth within Agbowa and Offin 4WAP

However, after the 12 Weeks After Planting (12 WAP), a reverse was recorded for the highest growth performance regarding maize height, number of leaf, leaf length, leaf width, leaf area and stalk girth was found in maize served with organic fertilizer in both study locations. This is followed by maize served with inorganic fertilizer and control treatments during the same planting period. The result 
thus suggests that inorganic fertilizer aids maize growth within short span while the reverse is the case for organic fertilizer. Comparatively, maize served with inorganic fertilizer in Agbowa had better growth performance than that of Offin. The observed difference may be attributed to differences in location, soil type and soil attributes.

However, the hypotheses were also tested statistically to ascertain whether or not there aresignificant differences in the growth of maize served with organic and inorganic fertilizers between and within locations in the study area.

Table 3: Statistical difference in maize growth within Agbowa 4WAP

\begin{tabular}{lllll}
\hline Groups & Count & Sum & Average & Variance \\
\hline ORGANIC & 6 & 18.59 & 3.098333 & 14.85562 \\
INORGANIC & 6 & 29.35 & 4.891667 & 27.13902 \\
CONTROL & 6 & 20.14 & 3.356667 & 19.68043 \\
\hline
\end{tabular}

ANOVA

\begin{tabular}{lllllll}
\hline Source & of & & & & & \\
Variation & SS & df & MS & F & P-value & F crit \\
\hline Between Groups & 11.27801 & 2 & 5.639006 & 0.274293 & 0.763841 & 3.68232 \\
Within Groups & 308.3753 & 15 & 20.55835 & & & \\
Total & 319.6533 & 17 & & & & \\
\hline
\end{tabular}

At a degree of freedom of 2:15, the $\mathrm{F}$ value of 0.275 and a Critical value of 3.682 P: $0.76>0.05$ the result shows that the differences in the field experiment were not statistically significant, hence the null hypothesis is accepted while the alternate hypothesis stating that there is significant difference in maize growth in Agbowa 4WAP was rejected. However, though similar growth patterns can be seen, observed differences can also be seen on the chart shown above.

Table 4: Statistical difference in maize growth within Offin 4WAP

\begin{tabular}{lllll}
\hline Groups & Count & Sum & Average & Variance \\
\hline ORGANIC & 6 & 14.97 & 2.495 & 11.82867 \\
INORGANIC & 6 & 19.01 & 3.168333 & 17.18514 \\
CONTROL & 6 & 14.69 & 2.448333 & 13.38162 \\
\hline
\end{tabular}

\begin{tabular}{lllllll} 
ANOVA & \multicolumn{1}{l}{} & & & \\
\hline Source & of & & & & & \\
Variation & SS & df & MS & F & P-value & F crit \\
\hline Between Groups & 1.947911 & 2 & 0.973956 & 0.068919 & 0.933696 & 3.68232 \\
Within Groups & 211.9771 & 15 & 14.13181 & & & \\
Total & 213.925 & 17 & & & & \\
\hline
\end{tabular}

At Offin, the analysis of variance at a degree of freedom of 2:15, the F value of 0.068 and a critical value of $3.682 \mathrm{P}: 0.93>0.05$, the result shows that the differences observed were not statistically significant either. 
Difference in the Growth of Maize Twelve Weeks after Planting (12WAP) within Agbowa and Offin

The result of the effect of organic and inorganic fertilizer on growth of maize as indicated on Figure 3 a\&b revealed that, the highest growth performance of maize height, number of leaf, leaf length, leaf

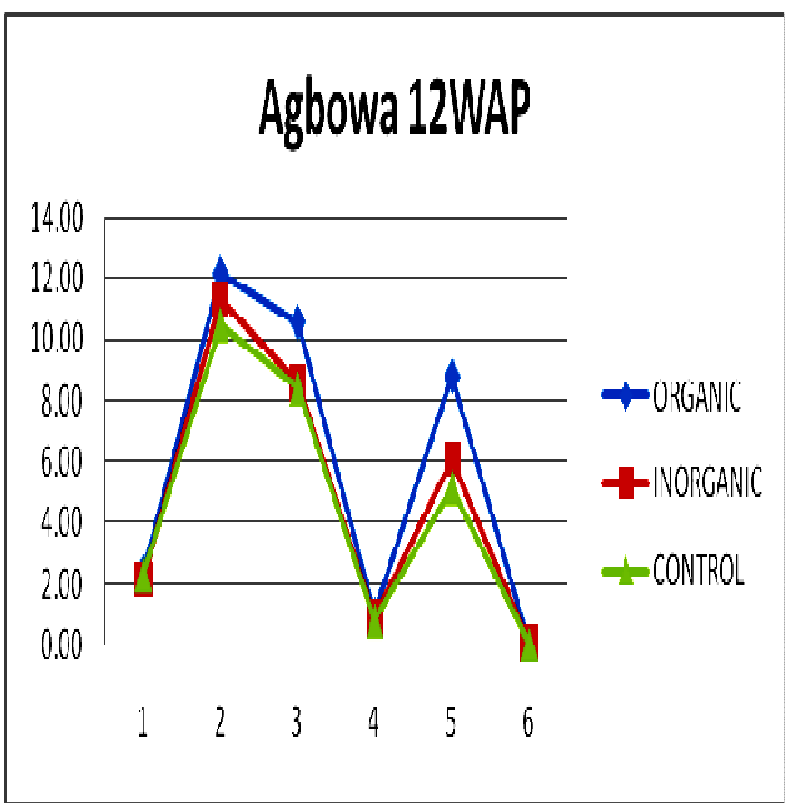

(a) width, leaf area and stalk girth 12 Weeks After Planting (12WAP) was found in maize served with inorganic fertilizer within each of the study locations (Agbowa \& Offin) while slight differences were noticed in the growth parameters between the organic fertilizer and control treatments during the same planting period.

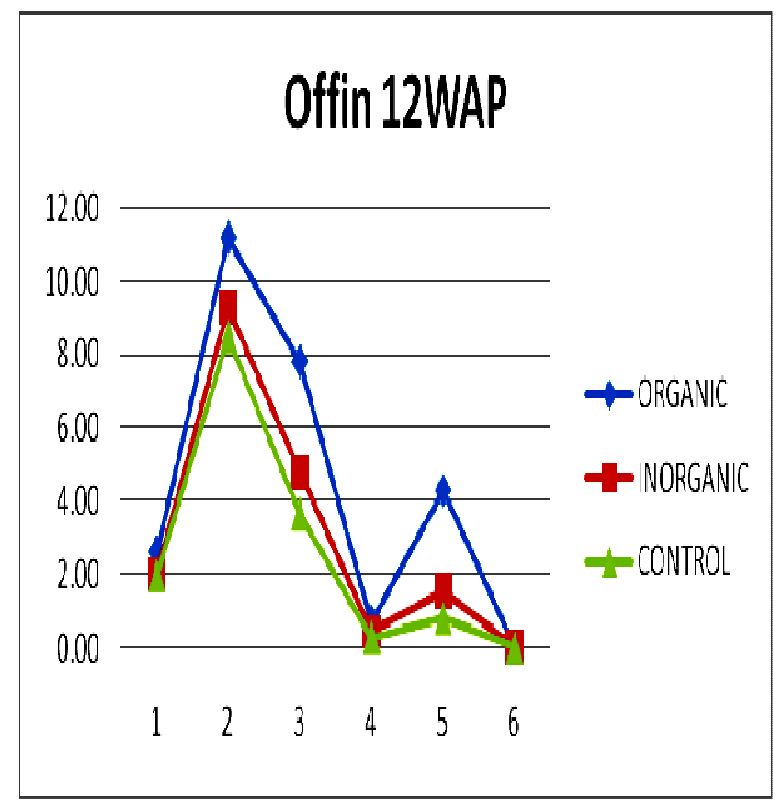

(b)

Figure 3a\&b: Estimated difference in maize growth within Agbowa and Offin 12WAP

Table 5: Statistical difference in maize growth in Agbowa 12WAP

\begin{tabular}{lllll}
\hline Groups & Count & Sum & Average & Variance \\
\hline ORGANIC & 6 & 35.17 & 5.861667 & 27.80718 \\
INORGANIC & 6 & 29.23 & 4.871667 & 20.5111 \\
CONTROL & 6 & 27.3 & 4.55 & 17.93104 \\
\cline { 2 - 5 }
\end{tabular}

\begin{tabular}{lllllll} 
ANOVA & & & & & & \\
\hline Source & of & & & & & \\
Variation & SS & df & MS & F & P-value & F crit \\
\hline Between Groups & 5.608078 & 2 & 2.804039 & 0.126977 & 0.881691 & 3.68232 \\
Within Groups & 331.2466 & 15 & 22.0831 & & & \\
Total & 336.8546 & 17 & & & & \\
\hline
\end{tabular}

Like the analysis of the $4 \mathrm{WAP}$, an analysis of variance was used to show the differencethat exists between maize growth in Agbowa $12 \mathrm{WAP}$ after applying organic, inorganic and the control samples. At a degree of freedom of 2:15, the F value of 0.127 and a Critical value of 3.682 P: $0.88>0.05$, the result as depicted on Tables 5\&6revealedthat the differences 
observed were not statistically significant, hence the null hypothesis was accepted while the alternate hypothesis was rejected.

Table 6: Statistical difference in maize growth in Offin 12WAP

\begin{tabular}{lllll}
\hline Groups & Count & Sum & Average & Variance \\
\hline ORGANIC & 6 & 26.66 & 4.443333 & 18.57379 \\
INORGANIC & 6 & 18.26 & 3.043333 & 12.30151 \\
CONTROL & 6 & 15.33 & 2.555 & 10.23571 \\
\cline { 2 - 5 }
\end{tabular}

\begin{tabular}{lllllll} 
ANOVA & \multicolumn{1}{l}{} & & & \\
\hline Source & of & & & & & \\
Variation & SS & Df & MS & F & P-value & F crit \\
\hline Between Groups & 11.52854 & 2 & 5.764272 & 0.420637 & 0.664138 & 3.68232 \\
Within Groups & 205.555 & 15 & 13.70367 & & & \\
Total & 217.0836 & 17 & & & & \\
\hline
\end{tabular}

\section{Statistical difference in Maize growth} between Agbowa and Offin

On the basis of any significant difference in maize growth between the two locations 4WAP at both Agbowa and Offin, the results showed that there was a significant difference with a $\mathrm{t}$ value of 3.794, P: $0.001<0.05$. This implies the null hypothesis that there is no significant difference in maize growth between the two locations 4 WAP was rejected while the alternate hypothesis was accepted.

Table 7: Statistical difference in maize growth between the two locations 4WAP?

\begin{tabular}{|l|l|l|l|l|l|}
\hline & & Mean & $\mathrm{N}$ & Std. Deviation & Std. Error Mean \\
\hline Pair 1 & AGBOWA 4WAP & 3.7822 & 18 & 4.33626 & 1.02207 \\
\cline { 2 - 6 } & OFFIN 4WAP & 2.7039 & 18 & 3.54737 & .83612 \\
\hline & \multicolumn{5}{|l}{} \\
\hline & & $\mathrm{N}$ & Correlation & Sig. \\
\hline Pair 1 & 4WAP AGBOWA \& Offin 4WAP & & .973 & .000 \\
\end{tabular}

\begin{tabular}{|c|c|c|c|c|c|c|c|c|c|c|}
\hline & & \multicolumn{5}{|c|}{ Paired Differences } & \multirow{3}{*}{$\mathrm{t}$} & \multirow[b]{3}{*}{ df } & \multirow{3}{*}{$\begin{array}{l}\text { Sig. } \\
\text { tailed) }\end{array}$} & \\
\hline & & \multirow[b]{2}{*}{ Mean } & \multirow{2}{*}{$\begin{array}{l}\text { Std. } \\
\text { Deviation }\end{array}$} & \multirow{2}{*}{$\begin{array}{l}\text { Std. Error } \\
\text { Mean }\end{array}$} & \multicolumn{2}{|c|}{$\begin{array}{|llr|}95 \% & \text { Confidence } \\
\text { Interval of the } \\
\text { Difference }\end{array}$} & & & & \\
\hline & & & & & Lower & Upper & & & & \\
\hline Pair 1 & $\begin{array}{l}\text { 4WAP AGBOWA } \\
\text { Offin 4WAP }\end{array}$ & 1.07833 & 1.20591 & .28424 & .47865 & 1.67802 & 3.794 & 17 & .001 & \\
\hline
\end{tabular}

On the basis of any significant difference in maize growth between the two locations 12 WAP at both Agbowa and Offin, the results showed that there was a significant difference with a $t$ value of 2.972 , P: $0.031<0.05$. This implies the null hypothesis that there was no significant difference in maize growth 
between the two locations 12 WAP was rejected while the alternate hypothesis will be accepted.

\section{Effect of Organic and Inorganic Fertilizers Use on Maize Yield}

As shown in Table 7 below, the following results were obtained from direct measurement of output/ yield parameters in an attempt to determine the effect of organic and inorganic manure on maize yield. The weight of harvested maize for the organic, inorganic and control samples in Agbowa $(3.8 \mathrm{~kg}, \quad 4.5 \mathrm{~kg} \& 3.2 \mathrm{~kg}$ respectively) are more than twice the weight of harvested maize for the organic, inorganic and control samples in Offin $(1.62 \mathrm{~kg}, 2.22 \mathrm{~kg} \& 0.14 \mathrm{~kg}$ respectively). Also, the length of harvested maize for the organic, inorganic and control samples in Agbowa $\quad(1.83 \mathrm{~kg}, \quad 1.06 \mathrm{~kg} \quad \& \quad 0.92 \mathrm{~kg}$ respectively) appear to be greater than the length of harvested maize for the organic, inorganic and control samples in Offin $(1.07 \mathrm{~kg}, \quad 0.93 \mathrm{~kg} \quad \& \quad 0.57 \mathrm{~kg}$ respectively).

Table 7: Field Measurement of Maize Yield Parameter - 12 weeks after planting

\begin{tabular}{llll|llll}
\hline \multicolumn{3}{c|}{ AGBOWA } & OFFIN & & \\
& COB & WEIGHT & COB \\
$(\mathrm{Kg})$ & LENGTH & $\begin{array}{l}\text { COB } \\
(\mathrm{Kg})\end{array}$ & WEIGHT & $\begin{array}{l}\text { COB } \\
(\mathrm{M})\end{array}$ & LENGTH \\
\hline ORGANIC & 3.8 & 1.83 & 1.62 & & 1.07 & \\
INORGANIC & 4.5 & 1.06 & 2.22 & 0.93 & \\
CONTROL & 3.2 & 0.92 & & 0.14 & 0.57 & \\
\hline
\end{tabular}

The statistical analysis to determine if there is no significant difference in the yield of maize served with organic and inorganic fertilizers between and within locations in the study area revealed that there a significant difference in maize yield within Agbowaand Offin, with t- value of 4.179, P: $0.009<0.05$ and $t$-value of 3.601 , P: $0.016<0.05$ respectively and between the two study locations at harvesting 12WAPi.e. at the $t$ value of
2.972, P: $0.031<0.05$. In asserting if there is any significant difference in maize yield between the two locations 12 WAP, the results showed that the maize yields differed significantly after 12 weeks of planting. The $\mathrm{T}$ test value of 2.972 , at a degree of freedom of 5 gave a P: 0.031 $<0.05$. This implies that there was a significant difference in the maize yield between the two locations. 


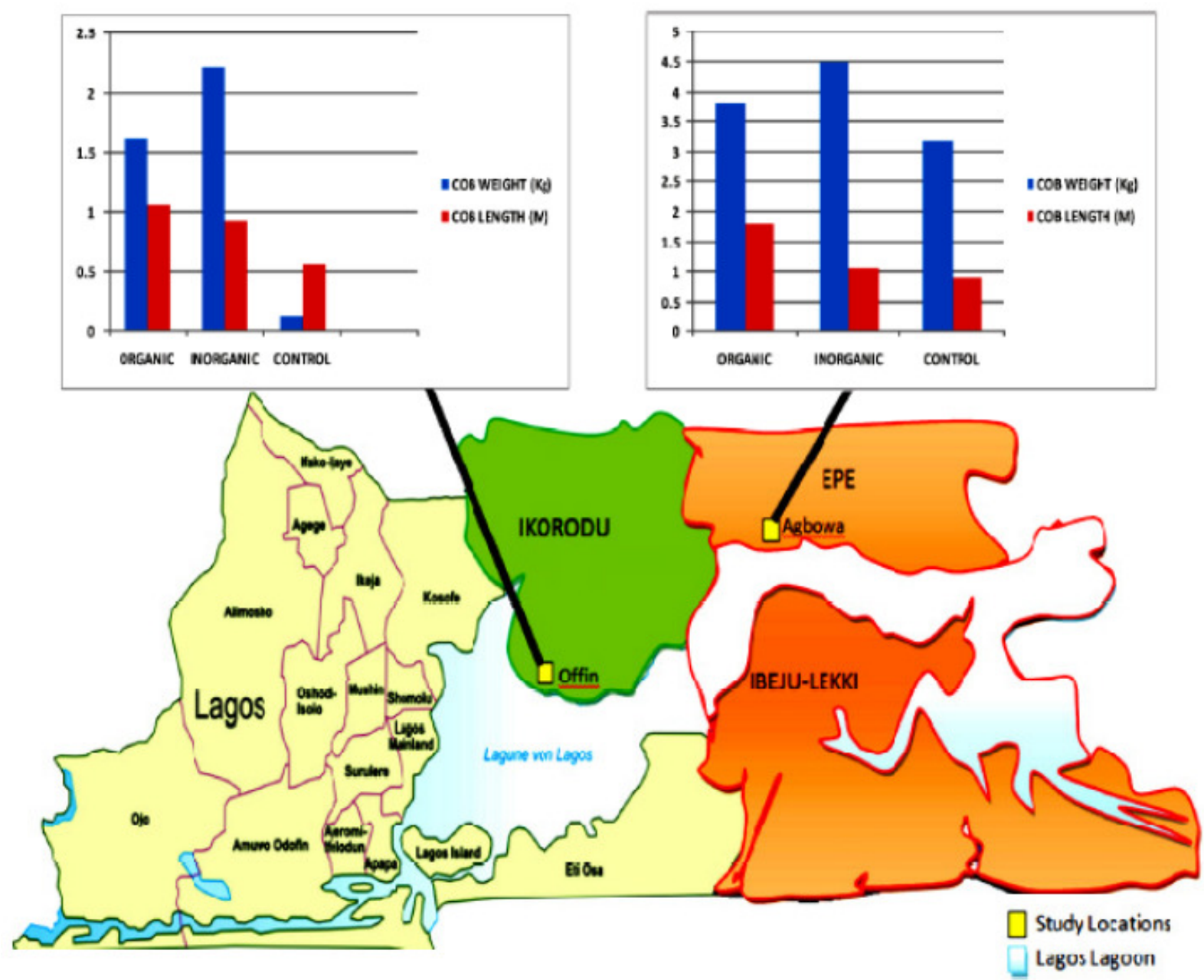

Map of Lagos State showing effect of organic and inorganic fertilizers on maize yield differences in Agbowa and Offin

Source: Retrieved from http://google.com and modified (2013)

\section{Conclusions}

The paper discussed the differences in the growth and yield of maize served with organic and inorganic fertilizers within and between two locations of relatively the same climatic region. The growth and yield maize within a location found to be similar whereas the differences between locations were found to be recorded signifying the possible influence local soil types and properties as well as other socioeconomic factors considering the fact that the climatic conditions of both Agbowa and Offin are the same. In addition, the difference in the yield of maize served with organic fertilizer and those served with inorganic fertilizer within each of the locations and between the two study locations could possibly be attributed to the capability of organic manure to improve soil structure, increase water holding capability. The paper thus concludes that farmers should be educated and equipped with practical skills to improve the use and application of all types of fertilizer for increased yield, income and sustainable maize production.

\section{Reference}

Boateng, S.A., Zickermann, A.J. and Kornaharens, M. (2002). "Effect of poultry manure on soil physical and 
chemical properties, growth and grain yield of sorghum in southwest Nigeria”. American-Eurasian Journal of Sustainable Agriculture, 2(1): 72-77.

Chandrashekara, R. and Riazuddin, M. (2000). Organic Agriculture: Sustainability market policies. CAB Organization for Economic Cooperation and Development p. 95.

Dhillon, S., Shivaram, B. and Sidhu, S. (2006). "Nitrogen and fate from long-term poultry litter applications to Oklahoman soils". Soil Science Society American Journal, 27: 11311137.

Ewulo, B.S. and Adeyemo, A.J. (2008). Nitrogen and phosphorus forms in soil receiving manure. Soil Science, 159: 253-258.

Georgia Environmental Protection Division GEPD (2012). Role of Nutrient Management plan on environmental sustainability. Journal of Tropical Agriculture, Food, Environment and Extension, 3:27-33

Hileman, L.H. (2008). Environmental impact of animal manure management: Livestock and Environment - finding a balance. International Agricultural Centre, Wageningen, (The Netherlands) p. 53.

International Institute of Tropical Agriculture (IITA) (2007). Maize Program Annual Report for 2007 Ibadan, Nigeria. Pp.1-2.

Iwena, O.A. (2008). Essential Geography for schools, Tonad publishers, Lagos, pp 82 - 110.

Iwena, O.A. (2012). Essential Agric. for schools, Tonad publishers, Lagos, pp $34-56$.

Jayaprakash, S.M., Dinesh, K.M., Nagamma, M.S. and Yishwanath, S.Y. (2006). Soil Drying and Soil fertility. Tropical Agriculture. Leswnand Hill, Longman pg 3-10.

Luiz, A. and Willey, J. (2008). Effects of poultry manure and/or inorganic fertilizer on the yield of shallot (Allium cepa var. aggregatum). Advance Horticulture Science, 16(1): 7-12.

Mahala, A.G., Mokhtar, A.M. and Amasaib, E.O. (2006). Prospects and potential of poultry manure. Asia Journal of Plant Sciences, 994: 172182.

Masood, K., Glassner, R. and Schetter, C. (2009). Facing up to Africa's food crisis. Foreign Affairs, 61(1): 154174.

Obafemi, M. (2010). Effects of cover crops on soil structure and yield of subsequent arable crops grown under strip tillage on an eroded alfisol. Soil Tillage Res., 2: 233-250.

Olulade, O.E. (2012). Histroy of Agbowa Ikosi in Ejinrin- Ikosi LCDA of Lagos State. Unpublished class note.

Onasanya, A. Banito, A.Dewa, K.M and Kpemoua, K.E. (2009). Growth and Yield Response of Maize (Zea mays L.) to Different Rates of Nitrogen and Phosphorus Fertilizers in Southern Nigeria. World Journal of Agricultural Sciences 5 (4): 400-407.

Onwueme, I.C. and Sinha, T.D. (2009). Complementary Organic and Inorganic Fertilizer Application: Influence on Growth and Yield of Cassava/maize/melon Intercrop with a Relayed Cowpea.

Romains, W. (2011). Fertile soil: A grower's guide to organic and inorganic fertilizers. Eg. Access.603 fourth St. Davids, A95616.

Subedi, K. D. and Gurung, G. (2010). Oil fertilizer thrust towards sustainable agriculture: experience of LumileRegional Agricultural Research 
centre. In: Soil Fertility and Erosion Issues in the Middle Mountains of Nepal pp. 81-82 IDRC, Ottawa, Canada.

Suryavamshi, M.V. and Aurangabad, N.B. (2008). Effect of Different Organic Manures and Inorganic Fertilizers on Growth, Yield and Quality of Carrot (Daucus carota L.) Karnataka Journal ofAgricultural Sciences, 20(3): (686-688).

Trinh, K., Moore, K., Wes, P.D., Muchowski, P.J., Dey, J., Andrews,
L. and Pallanck, L.J. (2008). Efficacy of organic amendments on the establishment and biomass yield of grass species on a degraded alfisol. $J$. Plant Interactions, 2(3): 195-201.

Yayock, J.Y., Menyonga, J.M. and Idrissa, S. (2006). Environmental impact of animal manure management. Livestock and Environmental. Finding a balance, International Agricultural Centre, Wageningen (the Netherlands) pages 53. 